\title{
HUBUNGAN STATUS GIZI IBU DENGAN STATUS GIZI BAYI USIA 5 - 6 BULAN YANG MENDAPAT ASI EKSKLUSIF
}

\author{
Fidya Ardiny, Arintina Rahayuni*) \\ Program Studi Ilmu Gizi Fakultas Kedokteran Universitas Diponegoro \\ Jl.Dr.Sutomo No.18, Semarang, Telp (024) 8453708, Email : gizifk@undip.ac.id
}

\begin{abstract}
Background : The government have established exclusive breastfeeding as a program to achieved Millenium Developmental Goal's (MDGs). Exclusive breastfeeding infant's depends only breastfeeding intake for 6 month. Maternal nutritional status influence the quantity and quality of breastfeeding. Infant who received enough breastfeeding could be expected the optimum nutritional status. The aim of this study was to investigating correlation between maternal nutritional status with nutritional status of 5 and 6 month old exclusive breastfeeding infant's.

Method : The cross sectional study design in Puskesmas Pandanaran and Ngemplak Simongan's area during May June. Sample were 35 exclusive breastfeeding infant with age 5 and 6 month used consecutive sampling. Data of characteristics and breastfeeding taken from questioner that filled by interview to mother's infant. Nutritional status of infant measured by Weight for Age Z Score (WAZ), and maternal nutritional status with BMI. Bivariat analysis used correlation Pearson product moment.

Result : The mean of baby WAZ is $(-0,114) \pm 1,00$; and maternal BMI is 23,93 $\pm 3,71$. There was no correlation between maternal nutritional status with nutritional status of 5 and 6 month old exclusive breastfeeding infant's. That may affected by domination of normoweight maternal, frequency and duration of breastfeed, and baby's birth weight.

Conclusion : There was no correlation between maternal nutritional status with nutritional status of 5 and 6 month old exclusive breastfeeding infant's.
\end{abstract}

Keywords : Exclusive breastfeeding; maternal nutritional status; infant nutritional status.

\begin{abstract}
ABSTRAK
Latar belakang : Pemerintah menetapkan progam ASI eksklusif untuk mencapai Millenium Developmental Goal's (MDG's). Bayi ASI eksklusif sangat bergantung pada asupan ASI saja selama 6 bulan. Status gizi ibu menyusui merupakan salah satu faktor yang mempengaruhi kuantitas dan kualitas ASI. Bayi yang mendapat cukup ASI diharapkan dapat mencapai status gizi optimal. Penelitian ini dilakukan untuk mengetahui hubungan status gizi ibu dengan status gizi bayi usia 5 dan 6 bulan yang mendapat ASI eksklusif.

Metode : Penelitian cross sectional dengan jumlah sampel sebanyak 35 bayi usia 5 dan 6 bulan yang dipilih secara consecutive sampling di wilayah kerja Puskesmas Pandanaran dan Ngemplak Simongan pada bulan Mei - Juni. Data identitas dan pemberian ASI eksklusif didapat melalui wawancara dengan ibu bayi. Status gizi bayi dinilai berdasarkan z-score BB/U, sedang status gizi ibu dinilai menggunakan IMT. Analisis bivariat menggunakan correlation Pearson product moment.

Hasil : Rerata z-score BB/U bayi adalah $(-0,114) \pm 1,00$. Rerata IMT ibu menyusui adalah 23,93 \pm 3,71. Tidak terdapat hubungan bermakna antara status gizi ibu dengan status gizi bayi usia 5 dan 6 bulan yang mendapat ASI eksklusif.

Simpulan : Tidak terdapat hubungan antara status gizi ibu dengan status gizi bayi usia 5 dan 6 bulan yang mendapat ASI eksklusif.
\end{abstract}

Kata kunci : ASI eksklusif; status gizi ibu menyusui; status gizi bayi.

\section{PENDAHULUAN}

Pemerintah menetapkan Rencana Aksi Pembinaan Gizi Masyarakat dengan salah satu indikator kinerjanya adalah Air Susu Ibu (ASI) eksklusif guna mendukung pencapaian Millenium Developmental Goals (MDGs). ${ }^{1}$ ASI merupakan makanan terbaik bagi bayi karena mampu mencukupi kebutuhan gizi serta melindungi bayi dari penyakit infeksi. ${ }^{2,3}$ Cakupan pemberian ASI
Eksklusif $0-5$ bulan di Indonesia pada tahun 2010 mencapai $15,3 \%{ }^{4}$

ASI sangat dibutuhkan untuk pertumbuhan bayi, namun tidak semua bayi yang mendapat ASI saja dapat tumbuh dengan baik. Asupan ASI yang tidak adekuat menyebabkan bayi berisiko mengalami kekurangan gizi. ${ }^{2,3}$ Prevalensi gizi buruk pada balita tahun 2010 adalah 5,4\% dan gizi kurang $13 \%$, sedang stunting $35,6 \%$, dan wasting $13,3 \%{ }^{4}$ Salah satu faktor yang mempengaruhi

${ }^{*}$ Penulis Penanggungjawab 
kuantitas dan kualitas ASI adalah status gizi ibu menyusui. Status gizi ibu menyusui mencerminkan kondisi gizi dan kesehatan ibu pada saat masa menyusui yang dapat diukur melalui antropometri tubuh ibu dengan indikator Indeks Massa Tubuh $(\text { IMT })^{5,6}$ Penelitian di Iran tahun 2003 menyatakan bahwa terdapat hubungan yang signifikan antara status gizi ibu yang diukur menggunakan IMT dengan status gizi bayi yang menggunakan indikator z-score $\mathrm{BB} / \mathrm{U}$. Z-score $\mathrm{BB} / \mathrm{U}$ merupakan indikator yang sensitif untuk mengetahui perubahan berat badan bayi dalam jangka waktu singkat. ${ }^{7}$

Kuantitas dan kualitas ASI dari ibu dengan status gizi baik lebih optimal dari pada ibu malnutrisi. Ibu yang berstatus gizi baik memiliki cadangan gizi yang cukup sehingga mampu memproduksi ASI dengan lancar dengan kandungan gizi yang cukup. ${ }^{2,3}$ Pada ibu severe underweight akan mengalami penurunan kuantitas dan kualitas ASI. ${ }^{8,9}$ Ibu obesitas (IMT $\geq 30$ ) memiliki hormon prolaktin lebih rendah sehingga lebih berisiko mengalami hambatan dalam proses menyusui. $^{10,11}$

Cadangan lemak tubuh ibu akan mempengaruhi kandungan lemak dalam ASI karena sekitar $60 \%$ lemak ASI berasal dari sintesis di jaringan dan cadangan di adiposa. Kandungan protein dalam ASI dipengaruhi oleh kadar protein dalam aliran darah ibu yang akan disintesis oleh kelenjar mamae. Kandungan karbohidrat dalam ASI sedikit dipengaruhi oleh status gizi ibu karena presentase kadar karbohidrat dalam ASI hampir sama pada setiap ibu. ${ }^{12,13}$ Volume, kandungan zat gizi, serta energi dalam ASI yang diasup oleh bayi merupakan satu - satunya sumber tenaga dan zat pembangun untuk pertumbuhan dan perkembangan bayi. Kurangnya produksi dan kandungan gizi dalam ASI menyebabkan pertumbuhan dan perkembangan bayi menjadi tidak optimal. Asupan yang cukup akan tercermin dengan penambahan berat badan bayi sesuai standar pertumbuhan, sehingga tercapai status gizi bayi normal. ${ }^{3}$

Adanya keterkaitan antara status gizi ibu dengan status gizi bayi perlu mendapat perhatian khusus, terutama dalam rangka pelaksanaan program ASI eksklusif, dimana bayi sangat bergantung pada ASI tanpa MPASI dan PASI selama 6 bulan. Pelaksanaan program ASI eksklusif harus tetap mempertimbangkan dampak terhadap status gizi bayi. Hal tersebut dilakukan untuk menghindari terjadinya kekurangan gizi yang menyebabkan bayi berisiko mengalami gizi buruk dan stunting, serta dapat mengoptimalkan status gizi bayi sesuai tujuan pelaksanaan ASI eksklusif.

\section{METODE PENELITIAN}

Penelitian dilakukan pada bayi usia 5 dan 6 bulan yang mendapat ASI eksklusif di wilayah kerja Puskesmas Pandanaran dan Ngemplak Simongan. Penelitian dilaksanakan pada bulan Mei - Juni 2013. Ruang lingkup penelitian ini merupakan penelitian gizi masyarakat dengan desain cross sectional. Jumlah bayi dalam penelitian ini sebesar 35 bayi yang didapat dengan consecutive sampling.

Krtiteria inklusi dalam penelitian ini adalah bayi usia 5 dan 6 bulan yang dihitung menggunakan bulan penuh, mendapat ASI saja dari lahir hingga waktu pelaksanaan penelitian dengan berat badan lahir $(\mathrm{BBL}) \geq 2500 \mathrm{~g}$, tidak sedang sakit dalam jangka 2 minggu sebelum pelaksanaan penelitian, dan tidak mengalami cacat bawaan.

Variabel independen adalah status gizi ibu yang memberikan ASI eksklusif. Variabel dependen adalah status gizi bayi yang mendapat ASI eksklusif. Status gizi ibu menyusui merupakan keseimbangan antara zat gizi yang diasup dan diserap oleh tubuh dengan kebutuhan gizi ibu menyusui, yang tercermin dari keadaan antropometri tubuh dan diukur dengan menggunakan IMT. IMT didapat dengan membagi BB dalam kg dengan kuadrat tinggi badan dalam meter $\left(\mathrm{kg} / \mathrm{m}^{2}\right)$. Status gizi bayi adalah keseimbangan antara zat gizi yang diasup dan diserap oleh tubuh dengan kebutuhan gizi bayi, yang tercermin dari keadaan antropometri tubuh dan diukur dengan menggunakan z-score $\mathrm{BB} / \mathrm{U}$. Zscore $\mathrm{BB} / \mathrm{U}$ dihitung menggunakan software $\mathrm{WHO}$ anthro 2005.

Data primer yang dikumpulkan adalah : data identitas ibu dan bayi, data antropometri, serta data tentang pemberian ASI eksklusif. Data sekunder berupa data bayi usia 5 dan 6 bulan yang didapat dari kelurahan, kader posyandu, dan puskesmas.

Tahap pertama yang dilakukan adalah wawancara dengan ibu yang bayinya memenuhi kriteria inklusi mengenai data identitas, antropometri, dan pemberian ASI eksklusif. Tahap berikutnya adalah penimbangan berat badan bayi serta penimbangan berat dan pengukuran tinggi badan ibu. Penimbangan berat badan bayi menggunakan baby scale dengan ketelitian $0,1 \mathrm{~kg}$, berat badan ibu dengan timbangan injak digital dengan ketelitian $0,1 \mathrm{~kg}$, serta pengukuran tinggi 
badan ibu dengan microtoice dengan ketelitian 1 $\mathrm{cm}$.

Data yang diperoleh kemudian dianalisis secara univariat dan bivariat. Analisis univariat dilakukan dengan memasukkan data untuk mendeskripsikan karakteristik bayi dan ibu, status gizi bayi, dan status gizi ibu. Hubungan status gizi bayi dan status gizi ibu dianalisis menggunakan uji korelasi Pearson product moment karena data berdistribusi normal.

\section{HASIL PENELITIAN}

\section{Karakteristik bayi}

Hasil penelitian menunjukkan bahwa sebagian besar bayi berjenis kelamin laki - laki $(57.1 \%)$ dan berusia 5 bulan $(68.6 \%)$. Rentang berat badan lahir bayi adalah 2,5 - 3,9 kg dengan rerata $3,06 \pm 0,34 \mathrm{~kg}$.
Tabel 1. Karakteristik Bayi Menurut Jenis Kelamin dan Usia

\begin{tabular}{lcc}
\hline Karakteristik & $\mathrm{N}$ & $\%$ \\
\hline Jenis Kelamin & & \\
$\quad$ Laki-laki & 20 & 57.1 \\
$\quad$ Perempuan & 15 & 42.9 \\
Umur & & \\
5 bulan & 24 & 68.6 \\
6 bulan & 11 & 31.4 \\
\hline Jumlah & 35 & 100 \\
\hline
\end{tabular}

\section{Karakteristik Ibu}

Usia ibu berkisar antara $19-38$ tahun dengan rerata $28,7 \pm 4,9$ tahun. Rerata usia ibu > 30 tahun adalah $33,85 \pm 1,86$ dengan rentang usia 31 - 38 tahun. Rata - rata pendidikan terakhir ibu adalah pendidikan dasar dan menengah atas $(37,1 \%)$, dan pekerjaan paling banyak adalah ibu rumah tangga $(91,4 \%)$. Sebagian besar ibu pernah melahirkan sebanyak 2 kali $(54.3 \%)$. Kategori jarak kelahiran yang paling banyak adalah antara 3 -6 tahun (25.7\%) dan $>6$ tahun (25.7\%).

Tabel 2. Kategori usia ibu

\begin{tabular}{lccccc}
\hline Kategori Usia Ibu & $\mathrm{N}$ & $\%$ & Mean $\pm \mathrm{SD}$ & $\begin{array}{c}\text { Nilai } \\
\text { minimum }\end{array}$ & $\begin{array}{c}\text { Nilai } \\
\text { maksimum }\end{array}$ \\
\hline$\leq 20$ th & 2 & 5.7 & $\begin{array}{c}19,50 \pm \\
0,71\end{array}$ & 19 & 20 \\
$21-30$ th & 20 & 57.1 & $\begin{array}{c}26,30 \pm \\
2,87\end{array}$ & 21 & 30 \\
$>30$ th & 13 & 37.1 & $\begin{array}{c}33,85 \pm \\
1,86\end{array}$ & 31 & 38 \\
\hline Jumlah & 35 & $100 \%$ & $\begin{array}{c}28,70 \pm \\
4,91\end{array}$ & 19 & 38 \\
\hline
\end{tabular}

Tabel 3. Karakteristik Ibu Menurut Pendidikan, Pekerjaan, Paritas, dan Jarak Melahirkan

\begin{tabular}{lcc}
\hline Karakteristik & $\mathrm{N}$ & $\%$ \\
\hline Pendidikan & & \\
$\quad$ Dasar $(9$ th) & 13 & 37.1 \\
Menengah atas (12 th) & 13 & 37.1 \\
Tinggi (>12 th) & 9 & 25.8 \\
Pekerjaan & & \\
$\quad$ Ibu Rumah Tangga & 32 & 91.4 \\
PNS/Guru & 2 & 5.7 \\
$\quad$ Swasta & 1 & 2.9 \\
Paritas & & \\
1 & 14 & 40.0 \\
2 & 19 & 54.3 \\
3 & 2 & 5.7 \\
Jarak Melahirkan & & \\
$\quad<3$ tahun & 3 & 8.6 \\
$3-6$ tahun & 9 & 25.7 \\
$>6$ tahun & 9 & 25.7 \\
\hline
\end{tabular}


Pemberian ASI Eksklusif

Sebagian besar frekuensi menyusui bayi berkisar pada rentang $10-15 x$ /hari $(74,3 \%)$ dengan rerata lama menyusui paling sering adalah 15 - 20 menit.

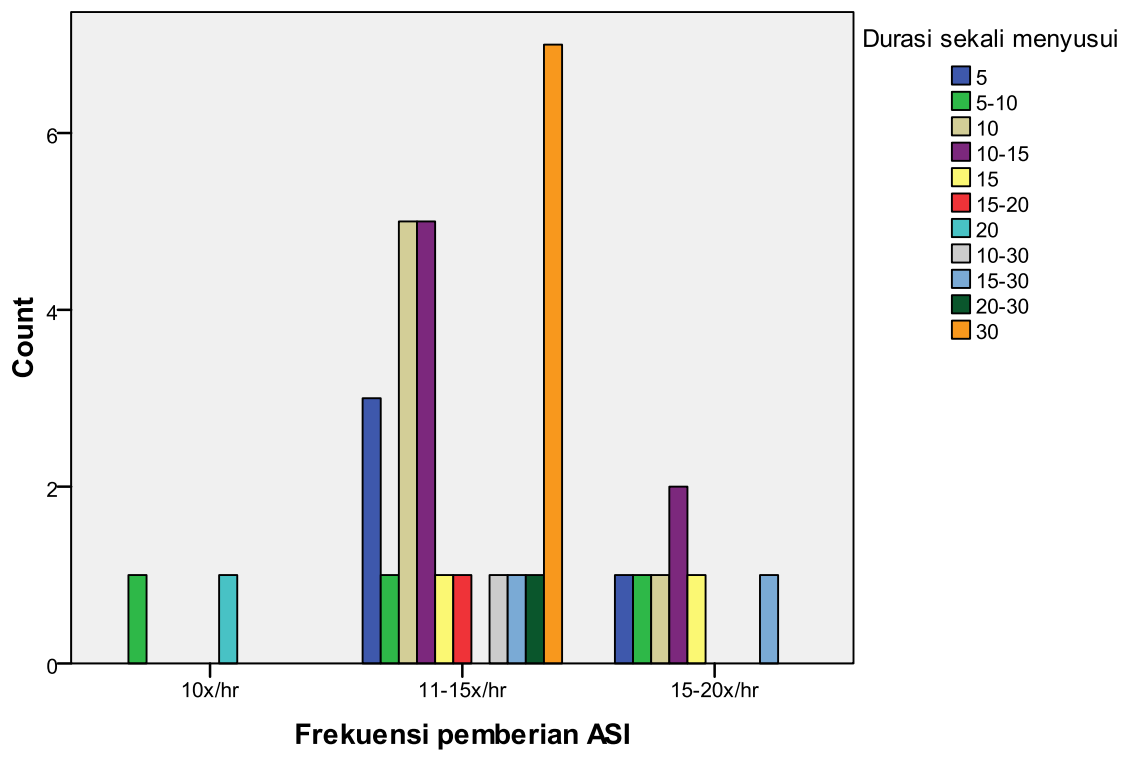

Grafik 1. Frekuensi dan Lama Menyusui

\section{Status Gizi Ibu}

Hasil penelitian menunjukkan rentang berat badan ibu antara 41,3 - 79,2 kg dengan rerata $55,33 \pm 9,73 \mathrm{~kg}$. Rentang tinggi badan ibu antara $137-165 \mathrm{~cm}$ dengan rerata $151,89 \pm 6,14 \mathrm{~cm}$.
Rentang status gizi ibu berdasar IMT adalah 18,75 $-33,83$ dengan rerata $23,94 \pm 3,71$. Sebagian besar kategori status gizi ibu adalah normoweight $(62,9 \%)$.

Tabel 4. Kategori Status Gizi Ibu Menurut IMT

\begin{tabular}{lccccc}
\hline Status Gizi Ibu & $\mathrm{N}$ & $\%$ & Mean \pm SD & $\begin{array}{c}\text { Nilai } \\
\text { minimum }\end{array}$ & $\begin{array}{c}\text { Nilai } \\
\text { maksimum }\end{array}$ \\
\hline Normoweight & 22 & 62.9 & $\begin{array}{c}21,63 \pm \\
1,93\end{array}$ & 18,75 & 24,77 \\
Overweight & 11 & 31.4 & $\begin{array}{c}27,07 \pm \\
1,56\end{array}$ & 25,02 & 29,64 \\
Obesitas & 2 & 5.7 & $\begin{array}{c}32,15 \pm \\
2,38\end{array}$ & 30,46 & 33,83 \\
& & & & & \\
\hline
\end{tabular}

\section{Status Gizi Bayi}

Penelitian ini menunjukkan rentang berat badan bayi 5,9 - 9,00 kg, dengan rerata 7,35 $\pm 0,79 \mathrm{~kg}$. Rentang status gizi bayi berdasar $z$-score $\mathrm{BB} / \mathrm{U}$ adalah $\quad(-2,22)-1,68$, dengan rerata $(-0,11) \pm 1.00$. Hanya terdapat satu bayi yang mengalami kategori status gizi kurang (2,9\%), sedang lainnya adalah status gizi baik $(97,1 \%)$.

Tabel 5. Kategori Status Gizi Bayi Menurut Z-score BB/U

\begin{tabular}{lccccc}
\hline Status Gizi Bayi & $\mathrm{N}$ & $\%$ & Mean \pm SD & $\begin{array}{c}\text { Nilai } \\
\text { minimum }\end{array}$ & $\begin{array}{c}\text { Nilai } \\
\text { maksimum }\end{array}$ \\
\hline Gizi Kurang & 1 & 2,9 & $\begin{array}{c}-2,22 \pm \\
0,00\end{array}$ & $-2,22$ & $-2,22$ \\
Gizi Baik & \multirow{2}{*}{3} & 97,1 & $\begin{array}{c}-0,05 \pm \\
0,95\end{array}$ & $-1,68$ & 1,68 \\
& & & & \\
\hline
\end{tabular}


Bayi yang mengalami gizi kurang berjenis kelamin laki - laki, berusia 6 bulan, dan berasal dari ibu normoweight. Z-score $\mathrm{BB} / \mathrm{U}$ bayi yang mengalami gizi kurang adalah $(-2,22)$, sedang IMT ibu adalah 18,75. Keduanya merupakan rentang paling bawah dalam pengukuran status gizi yang diperoleh.

Tabel 6. Kategori Status Gizi Bayi Berdasar Jenis Kelamin, Usia Bayi, dan Status Gizi Ibu

\begin{tabular}{|c|c|c|c|c|c|c|c|c|c|c|}
\hline \multirow{3}{*}{ Variabel } & & \multicolumn{6}{|c|}{ Kategori Status Gizi Bayi } & \multirow{2}{*}{\multicolumn{3}{|c|}{ Total }} \\
\hline & & \multicolumn{3}{|c|}{ Gizi Kurang } & \multicolumn{3}{|c|}{ Gizi Baik } & & & \\
\hline & & $\mathrm{N}$ & $\%$ & $z$-score & $\mathrm{N}$ & $\%$ & Mean \pm SD & $\mathrm{N}$ & $\%$ & Mean \pm SD \\
\hline $\begin{array}{l}\text { Jenis } \\
\text { Kelamin }\end{array}$ & Laki - laki & 1 & 100 & $-2,22$ & $\begin{array}{l}1 \\
9\end{array}$ & 59,9 & $\begin{array}{c}-0,15 \pm \\
0,99\end{array}$ & $\begin{array}{l}2 \\
0\end{array}$ & 57,1 & $\begin{array}{c}-0,29 \pm \\
1,07\end{array}$ \\
\hline Bayi & Perempuan & - & & - & $\begin{array}{l}1 \\
5\end{array}$ & 44,1 & $0,13 \pm 0,88$ & $\begin{array}{l}1 \\
5\end{array}$ & 42,9 & $0,13 \pm 0,88$ \\
\hline Usia Bayi & 5 bulan & - & & - & $\begin{array}{l}2 \\
4\end{array}$ & 70,6 & $0,13 \pm 0,97$ & $\begin{array}{l}2 \\
4\end{array}$ & 68,6 & $0,13 \pm 0,97$ \\
\hline & 6 bulan & 1 & 100 & $-2,22$ & $\begin{array}{l}1 \\
0\end{array}$ & 29,4 & $\begin{array}{c}-0,47 \pm \\
0,78\end{array}$ & $\begin{array}{l}1 \\
1\end{array}$ & 31,4 & $\begin{array}{c}-0,65 \pm \\
0,90\end{array}$ \\
\hline Status Gizi & Normoweight & 1 & 100 & $-2,22$ & $\begin{array}{l}2 \\
1\end{array}$ & 61,8 & $\begin{array}{c}-0,17 \pm \\
0,94\end{array}$ & $\begin{array}{l}2 \\
2\end{array}$ & 62,9 & $\begin{array}{c}-0,27 \pm \\
1,02\end{array}$ \\
\hline Ibu & Overweight & - & & - & $\begin{array}{l}1 \\
1\end{array}$ & 32,4 & $0,20 \pm 1,00$ & $\begin{array}{l}1 \\
1\end{array}$ & 31,4 & $0,20 \pm 1,00$ \\
\hline & Obesitas & - & & - & 2 & 5,9 & $\begin{array}{c}-0,21 \pm \\
0,89\end{array}$ & 2 & 5,7 & $\begin{array}{c}-0,21 \pm \\
0,89\end{array}$ \\
\hline
\end{tabular}

\section{Hubungan status gizi ibu dengan status gizi} bayi

Hasil uji korelasi Pearson product moment menunjukkan tidak terdapat hubungan yang signifikan antara status gizi ibu (IMT) dengan status gizi bayi (z-score $\mathrm{BB} / \mathrm{U})$. Hasil uji menunjukkan korelasi positif namun tidak bermakna secara statistik. $(r=0,254 ; p=0,141)$.

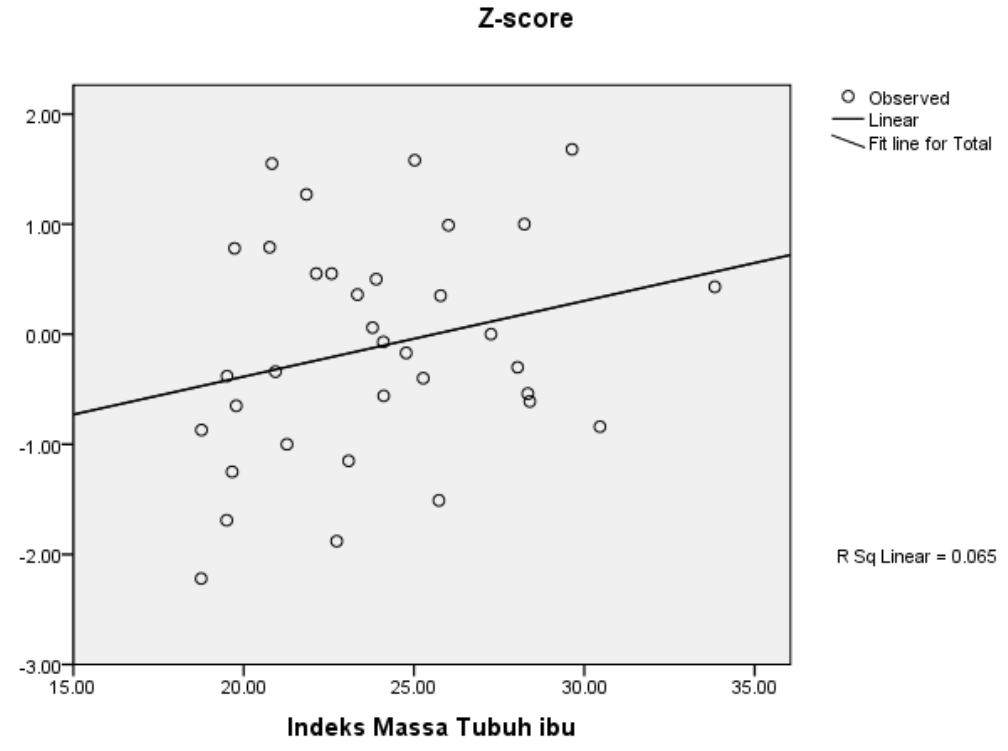

\section{PEMBAHASAN}

ASI merupakan makanan terbaik bagi bayi. Pelaksanaan ASI eksklusif tahun 2010 di Indonesia $(15,6 \%)$ lebih rendah jika dibanding dengan negara berkembang $(39,0 \%){ }^{14}$ Jenis kelamin bayi paling banyak dalam penelitian ini adalah laki - laki (58,3\%). Sebagian besar usia bayi adalah 5 bulan $(68,6 \%)$. Durasi pemberian ASI eksklusif yang dianjurkan oleh WHO adalah selama 6 bulan atau 180 hari awal kehidupan. ${ }^{15}$ Rerata $z$-score $\mathrm{BB} / \mathrm{U}$ bayi usia 5 bulan lebih tinggi dari pada usia 6 bulan, yaitu $0,13 \pm 0,97$ dan ($0,65) \pm 0,90$. Kebutuhan energi bayi usia $3-5$ bulan adalah $500 \mathrm{kkal} / \mathrm{hari}$, sedang usia 6 - 8 bulan 
sebesar $600 \mathrm{kkal} / \mathrm{hari}$. ASI dapat mencukupi kebutuhan bayi selama 6 bulan pertama. ${ }^{15}$ Pada bayi usia $>6$ bulan, terdapat peningkatan kebutuhan energi yang dapat dicukupi dengan mulai memperkenalkan MPASI dan melanjutkan pemberian ASI hingga mencapai usia 2 tahun. ${ }^{14,16}$ Pemberian ASI eksklusif yang terlalu lama dapat mengakibatkan kekurangan pemenuhan energi bagi bayi sehingga berisiko mengalami gizi kurang. Penelitian yang dilakukan oleh Michael S Kramer et al mengenai durasi pemberian ASI eksklusif menyatakan bahwa z-score $\mathrm{BB} / \mathrm{U}$ bayi yang mendapat ASI eksklusif usia 3 - 6 bulan lebih tinggi dari pada usia 1 - 3 bulan dan 6 - 9 bulan. ${ }^{17}$

Terdapat $42,9 \%$ ibu dengan usia $\leq 20$ tahun dan >30 tahun. Ibu dengan usia tersebut lebih berisiko mengalami gangguan dalam proses melahirkan dan bayi lahir prematur karena fungsi fisiologis rahim ibu belum siap atau telah menurun. ${ }^{18}$ Sebagian besar ibu $(60 \%)$ merupakan multipara atau melahirkan $\geq 2$ kali. Semakin banyak jumlah anak (>3) maka cadangan gizi ibu bagi pertumbuhan bayi akan berkurang, serta pola asuh menjadi tidak optimal. ${ }^{18}$ Kandungan protein dalam ASI ibu primipara lebih tinggi dibanding ibu multipara. ${ }^{12}$ Rentang jarak kelahiran sebelumnya berkisar antara 2,5 - 13 tahun. Sebanyak 8,6\% ibu melahirkan bayi dengan jarak kelahiran $<3$ tahun, dan $25,7 \%$ dengan jarak $>6$ tahun. Jarak yang terlalu rapat ( $<3$ tahun) meningkatkan risiko bayi lahir prematur dan mortalitas pada bayi. Jarak yang terlalu jauh ( $>6$ tahun) meningkatkan risiko preeklamsia pada ibu melahirkan. ${ }^{19}$ Ibu dengan usia risiko, jumlah anak yang terlalu banyak, dan jarak kelahiran yang terlalu rapat atau jauh akan berdampak pada status gizi bayi karena tubuh ibu belum siap dalam mencukupi cadangan gizi bagi pertumbuhan bayi di dalam kandungan serta guna memproduksi ASI secara optimal. ${ }^{18,19}$

Rerata z-score $\mathrm{BB} / \mathrm{U}$ bayi dari ibu overweight $(0,20 \pm 1,01)$ lebih tinggi dari pada normoweight $(-0,27 \pm 1,02)$ dan obesitas $(-0,21 \pm$ $0,89)$. Rentang IMT ibu adalah 18,75 - 33,83 dengan rerata $23,94 \pm 3,7$. Peningkatan berat badan ibu akan mempengaruhi volume dan kandungan gizi pada ASI, sedang peningkatan tebal lemak trisep akan mempengaruhi peningkatan konsentrasi lemak dan energi pada ASI. ${ }^{20}$ Status gizi bayi dari ibu yang memiliki kandungan lemak ASI > $3 \mathrm{~g} / \mathrm{dl}$, lebih tinggi dari pada bayi dari ibu yang lemak ASI-nya $<3$ g/dl. ${ }^{7,20}$ Studi yang dilakukan oleh World Health Organitation (WHO) menyimpulkan bahwa kandungan lemak ASI dari negara berkembang umumnya lebih rendah dari pada negara maju. ${ }^{15}$ Kandungan protein ASI tercermin pada jumlah protein yang terdapat dalam aliran darah ibu, terutama untuk protein non-nitrogen (kreatinin, peptida hormon, dan asam amino bebas seperti taurin, asam glutamat). Ibu yang memiliki sistem imunitas baik, memiliki kandungan zat - zat protektif dalam ASI lebih banyak dari pada ibu dengan imunitas yang sedang terganggu. ${ }^{12,13}$

Rerata asupan ASI bayi di negara berkembang adalah $750-850 \mathrm{ml} /$ hari dengan rentang $450 \mathrm{ml}$ hingga $1.200 \mathrm{ml} / \mathrm{hari} .{ }^{16}$ Produksi ASI dari ibu yang mengalami severe malnutrition akan turun $100-200 \mathrm{ml} /$ hari. Kandungan protein dan laktosa akan dijaga agar tetap tinggi, namun kandungan lemak, energi, dan vitamin sangat tidak adekuat bagi bayi. ${ }^{15}$ Ibu obesitas (IMT $\geq 30$ ) akan mengalami gangguan pada awal menyusui karena terjadi keterlambatan laktogenesis II atau produksi ASI. Hal tersebut berkaitan dengan kekurangan hormon prolaktin sehingga menghambat produksi ASI. Faktor yang mengakibatkan keterlambatan laktogenesis antara lain : tebalnya jaringan adiposa yang menghambat penurunan konsentrasi hormon progesteron (merupakan penekan fungsi hormon prolaktin), dan adanya penyimpangan endrokinologi. ${ }^{21,22}$ Penelitian mengenai laktasi di Amerika menunjukkan adanya gangguan regulasi glukosa yang merupakan substrat utama untuk mensintesis susu pada proses laktasi tikus obesitas. $^{22}$

Terdapat satu bayi yang mengalami gizi kurang (z-score $\mathrm{BB} / \mathrm{U}-2,22)$. Bayi tersebut berusia 6 bulan dengan jenis kelamin laki - laki dan berasal dari ibu normoweight dengan IMT 18,5. IMT ibu belum memenuhi IMT bagi ibu menyusui yang direkomendasikan oleh Institute of Medicine USA $(19,8$ - 26,0) Ibu yang termasuk dalam rentang IMT 19,8 - 26,0 diharap tidak akan mengalami gangguan dalam proses menyusui dan mampu menyediakan ASI yang adekuat bagi pertumbuhan bayi. ${ }^{23}$ Ibu dari bayi gizi kurang juga merupakan seorang ibu pekerja, dimana waktu untuk menyusui secara langsung lebih sedikit dibanding ibu rumah tangga. Hal tersebut akan mengurangi kesempatan untuk menyusu sekehendak bayi sehingga pemenuhan kebutuhan bayi menjadi kurang optimal. Produksi ASI ibu pekerja lebih sedikit dibanding dengan ibu yang tidak bekerja. Kondisi tersebut dapat diakibatkan oleh faktor beban fisik dan psikis berkaitan dengan pekerjaan ibu. $^{24}$

Hasil penelitian ini menunjukkan bahwa tidak terdapat hubungan antara status gizi ibu dengan status gizi bayi. Hal tersebut berkaitan 
dengan status gizi ibu yang didominasi oleh normoweight dengan IMT ibu paling rendah adalah 18,75, dimana kuantitas dan kualitas ASI yang dihasilkan tetap konstan dan dapat mencukupi kebutuhan gizi bayi secara adekuat. ${ }^{3,15,16} \mathrm{Hal}$ ini akan berbeda pada kuantitas dan kualitas ASI ibu severe underweight (IMT <16) yang akan menurunkan secara nyata sehingga tidak dapat mencukupi kebutuhan gizi bayi secara adekuat. Asupan bayi yang kurang akan menyebabkan status gizi bayi menurun. ${ }^{8,9,15}$

Frekuensi dan lama menyusu bayi sangat berpengaruh terhadap asupan bayi. ${ }^{3,4}$ Frekuensi dan lama menyusu bayi dalam penelitian ini sangat bervariasi. Semua bayi menyusu $>7 \mathrm{kali} / \mathrm{hari}$ dengan durasi > 10 menit tiap sekali menyusu. Bayi yang sering menyusu akan menstimulus produksi ASI lebih banyak meskipun pada ibu dengan kuantitas ASI yang kurang optimal. Rangsangan tersebut akan mempengaruhi peningkatan hormon prolaktin dan oksitosin yang berfungsi dalam produksi dan pengeluaran ASI sehingga jumlah ASI yang diproduksi mampu mencukupi kebutuhan bayi. ${ }^{3,4}$ Kecukupan asupan ASI dapat terlihat dari penambahan berat badan bayi hingga mencapai dua kali BBL pada usia 5 - 6 bulan, bayi berstatus gizi baik atau tumbuh sesuai standar, buang air kecil (BAK) >6 kali/hari, dan buang air besar (BAB) $2 x /$ hari. $^{15}$

ASI yang diasup oleh bayi akan digunakan sebagai sumber energi dan zat pembangun guna mencapai pertumbuhan dan perkembangan bayi secara optimal. Selain dari asupan, status gizi bayi juga dipengaruhi secara langsung oleh infeksi. ${ }^{3}$ Pada bayi yang mengalami infeksi, kebutuhan energi dan zat gizi akan meningkat namun bayi menjadi enggan menyusu sehingga jumlah asupan menurun. Hal tersebut berdampak pada penurunan berat badan bayi. ${ }^{15,16}$ Pada penelitian ini, riwayat penyakit bayi hanya diketahui pada saat terakhir sakit, tidak dapat mengetahui riwayat penyakit secara keseluruhan. Berat badan lahir (BBL) juga berpengaruh terhadap status gizi bayi. Pada penelitian di India tahun 2008 menyatakan bahwa $\mathrm{BBL}$ memiliki hubungan terhadap z-score $\mathrm{BB} / \mathrm{U}$. Bayi dengan $\mathrm{BBL}>4000 \mathrm{~g}$ lebih berpotensi mengalami obesitas, dan BBL $<2500 \mathrm{~g}$ berisiko mengalami gizi kurang apabila kebutuhan gizi tidak dipenuhi secara optimal. ${ }^{25}$

\section{SIMPULAN}

Penelitian ini menunjukkan tidak terdapat hubungan yang signifikan antara status gizi ibu dengan status gizi bayi usia 5 dan 6 bulan yang mendapat ASI eksklusif.

\section{UCAPAN TERIMA KASIH}

Puji syukur penulis panjatkan kehadirat Allah SWT, atas rahmat dan segala kemudahan yang telah diberikan. Penulis mengucapkan terima kasih kepada Dosen penguji dan pembimbing atas kritik dan saran yang telah diberikan. Terima kasih atas waktu dan kerjasamanya selama penelitian kepada Ibu kader dan ibu di wilayah puskesmas Pandanaran dan Ngemplak Simongan. Terima kasih pula kepada orang tua dan keluarga atas doa serta dukungannya. Terima kasih kepada temanteman gizi UNDIP angkatan 2009 atas dukungannya serta semua pihak yang telah membantu berjalannya penelitian ini

\section{DAFTAR PUSTAKA}

1. Widodo Y. Cakupan Pemberian ASI Eksklusif : Akurasi dan Interprestasi Data Survei dan Laporan Program. Gizi Indon 2011, 34 (2) : $101-108$.

2. Riordan J, Wambach K. Breastfeeding and Human Lactation Edition $4^{\text {th }}$. Canada: Jones and Bartlelt Publisher. 2010.

3. Lawrence RA, Lawrence RM. Breastfeeding : for Medical Professional. UK : Elsevier Health Sciences. 2010.

4. Riset Kesehatan Dasar. Jakarta : Badan Penelitian Kesehatan Kementrian Kesehatan RI. 2010.

5. Anne KNP, Judith NL, Enyong OJ. Factors Associated with Breastfeeding as Well as the Nutritional Status of Infants (0-12) Months: An Epidemiological Study in Yaounde, Cameroon. Pakistan Journal of Nutrition 6 (3): 259-263, 2007.

6. Hatsu IE, McDougals DM, Anderson AK. Effect of Infant Feeding on Maternal Body Composition. International Breastfeeding Journal 2008, 3:18.

7. Nikniaz L, Mahdavi R, Arefhoesseini SR, Khiabani MS. Association Between Fat Content of Breast Milk and Maternal Nutritional Status and Infants Weight in Tabriz, Iran. Mal J Nutr 15 (1) : $37-44,2009$.

8. Dewey KG, Cohen RJ, Brown KH, Rivera LL. Effects of Exclusive Breastfeeding for Four versus Six Months on Maternal Nutritional Status and Infant Motor Development: Results of Two Randomized Trials in Honduras. J Nutr 131:262267,2001.

9. Wachs TD. Models Linking Nutritional Deficiencies to Maternal and Child Mental Health. Am J Clin Nutr 2009;89(suppl):935S-9S.

10. Anstey EH, Jevitt C. Maternal Obesity and Breastfeeding. A Review of the Evidence and Implications for Practice. Clinical Lactation, 2011, Vol. 2-3, 11-16. 
11. Mok E, Multon C, Piguel L, Barroso E, Goua V, Christin P. Decreased Full Breastfeeding, Altered Practices, Perceptions, and Infant Weight Change of Prepregnant Obese Women: A Need for Extra Support. Pediatrics 2008;121;e1319.

12. Emmet PM, Rogers IS. Properties of Human Milk and Their Relationship With Maternal Nutrition. Early Human Development 49 Supp (1997) S7S28. Elsevier Scient Ireland Ltd. 1999.

13. Blackburn ST. Maternal, Fetal, and Neonatal Physiology. UK : Elsevier Health Sciences. 2012.

14. Cai Xiaodong, Wardlaw Tessa, Brown DW. Global Trends in Exclusive Breastfeeding. International Breastfeeding Journal 2012, 7:12.

15. World Organization Health. Infant and Young Child Feeding. Switzerland: WHO Press. 2009.

16. Walker WA, Watkins JB, Duggan C. Nutritional in Pediatrics Edition $4^{\text {th }}$. Basic Science and Clinical Application. Canada : BC. Decker Inc. 2008.

17. Kramer MS, Guo T, Platt RW, Vanilovich I, Sevkovskaya Z, Dzikovich I, et al. Feeding Effects on Growth During Infancy. J Pediatr 2004;145:600-5.

18. Haaga John G. Mechanism for the Association of Maternal Age, Parity, and Birth Spacing with Infant Health. USA : RAND. 1991.

19. Agudelo AC, Bermudez AR, Castano F, Norton MH. Effects of Birth Spacing on Maternal, Perinatal, and Child Health : A systemic Review of Causal Mechanisms. Study of Family Planning 2012; 43[2]: 93-114.

20. Brown KH, Akhtar NA, Robertson AD, Ahmed MG. Lactational Capacity of Marginally Nourished Mothers: Relationships Between Maternal Nutritional Status and Quantity and Proximate Composition of Milk. Pediatrics. 1989 Nov;78(5):909-19.

21. Coad Jane, Dunstall Melvyn. Anatomy and Physiology for Midwife Third Edition. UK : Elsevier Ltd. 2011.

22. Dewey KG, Heinig MJ, Cohen RJ. Risk Factors for Suboptimal Infant Breastfeeding Behaviour, Delayed Onset of Lactation, and Excess Neonatal Weight Loss. Pediatrics 2003; 112; 607.

23. Littleton LY, Engebretson JC. Maternal, Neonatal, and Women Health Nursing. USA: Thomson Learning Inc. 2002.

24. Ulya AM. Factors Influence of Worker Maternal Perseption with Exclusif Breastfeeding. JGP;2010:2(2):13-25.

25. Nutritional Status in Infancy and Early Childhood [editorial]. IYCN 2008; 7.5: 199-219. 